\title{
Aspects on Some Problems of Geotechnical Chemistry
}

by Rolf Söderblom

\section{STATENS GEOTEKNISKA INSTITUT \\ BIBLIOTEKET}

Reprinted from Geologiska föreningens i Stockholm förhandlingar bd 821960 H 3 


\section{Preface}

The report presented here is a preliminary description of some chemicai research work performed in connection with the investigations of quick clay deposits, mainly in the Göta River Valley.

After the first presentation of the results, the work has proceeded and the following should be added. As mentioned in the report, only some types of organic material possess dispersing properties, but there are also other types which seem to be of importance, as can be seen from consistency determinations. Reactions of the organic matter in the ground, e.g. oxidation from percolating water, may change the clay properties.

The study of the reactions, however, meets with difficulties in the separating of organic gels from minerals. Destruction of humus by hydrogenperoxide will change the behaviour of the clay. Thus, an increase of the salt content in the pore water will then not cause a stiffening of the clay. Interpretation of the test is rather intricate, owing to the obscurity of the influence on the mineral part.

Details from further investigations will be published later.

Stockholm, December, 1960.

SWEDISH GEOTECHNICAL INSTITUTE 
Fig. 1. Influence of alkali on the $\mathrm{H}_{1}$-value of a humic penetrated clay from Rosenkälla, Sweden (K 6766 sample 8124).

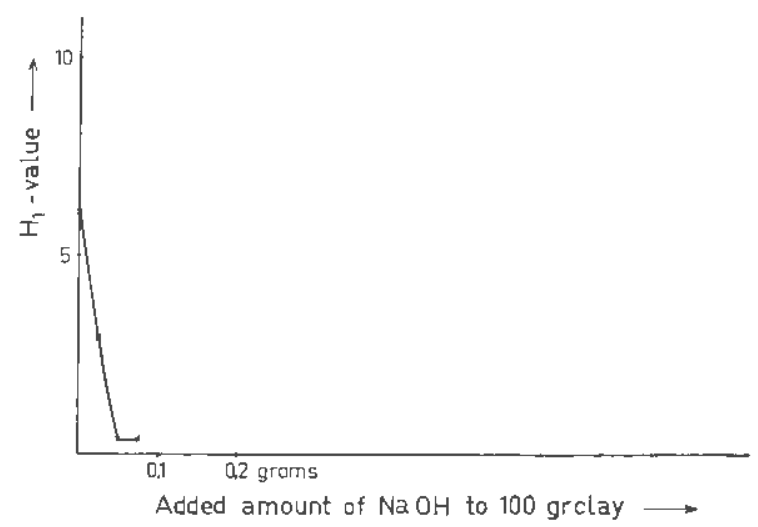

theoretical conceptions of the influence of dispersing agents, this clay sthould be quick when treated with alkali, which is shown in Table 1. The clay from this site is gencrally not quick owing to the fact that it is not sufficiently alkaline.

All conditions for quick clay formation of this kind are fulfilled at a site very close to the railway line hetween Broddby and Rosshyttan. A schematic view of the deposits is shown in Fig. 2. 'The peat deposit is about $2.9 \mathrm{~m}$ thick and, below this, there is a layer of postglacial clay ahout $0.2 \mathrm{~m}$ thick, followed by varved glacial clay. As shown in Fig. 4, the high sensitive clay hegins at $3.5 \mathrm{~m}$ below ground surface and the sensitivity increases towarts the hottom. The quick clay is found in the varved part of the clay deposit.

The laboratory examination performed on a corc taken from this site gave the following results. The clay profile is in its full length permeated by humic acid from the peat deposit, which constitutes a dispersing agent for clay in alkaline solution. Thus, the $\mathrm{H}_{1}$-value and the sensitivity of this clay profile depends on the $\mathrm{pH}$-value. When a sample having a rather high $\mathrm{H}_{1}$-ratue is treated with sodium hydroxide, the $\mathrm{H}_{1}$-value will change as shown in Fig. 3 . A slight change in $\mathrm{pH}$ may cause a sharp change in $\mathrm{H}_{1}$ which shows that there can be very small differences in $\mathrm{pH}$ between sensitive and insensitive clays.

Table 1. The effect of alkaline solutions on humic-infiltrated clay

(Sample 4155, K 6766, Rosenkälla, Swcdcn)

\begin{tabular}{|c|c|c|c|c|}
\hline \multirow{2}{*}{ Treatment during 48 hours } & \multicolumn{3}{|c|}{ Cone tests } & \multirow{2}{*}{ Notes } \\
\hline & $\mathrm{H}_{s}$ & $\mathrm{H}_{1}$ & $\mathrm{H}_{3} / \mathrm{H}_{1}$ & \\
\hline Nonc & 67.4 & 11.3 & 6.0 & \\
\hline Water & 25.0 & 1.37 & 18.3 & \\
\hline $0.1 \mathrm{~g} \mathrm{NaOH}$ in $0.51 \mathrm{H}_{2} \mathrm{O}$ & 39.5 & 0.43 & 91.9 & The clay will dissaggregate into dis- \\
\hline $0.2 \mathrm{~g} \mathrm{NaOH}$ in $0.5 \& \mathrm{H}_{2} \mathrm{O}$ & 22,8 & $<0.34$ & $>67.0$ & The surfacc disintegrated. \\
\hline $0.3 \mathrm{~g} \mathrm{NaOH}$ іл $0.51 \mathrm{H}_{2} \mathrm{O}$ & 10.2 & $<0.34$ & $>30.0$ & The surface disintegraced. \\
\hline $0.5 \mathrm{~g} \mathrm{NaOH}$ in $0.51 \mathrm{H}_{\mathrm{g}} \mathrm{O}$ & 16.5 & 1.37 & 12.0 & The sample quite destroyed. \\
\hline
\end{tabular}




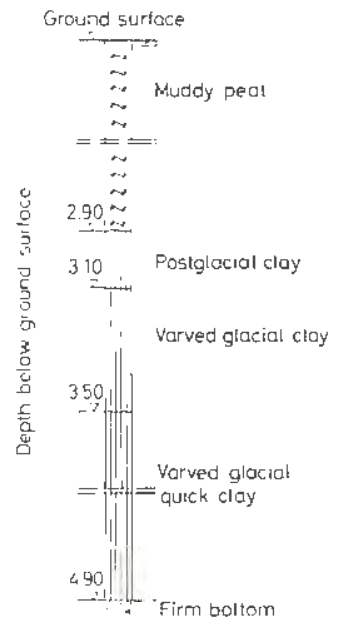

Fig. 2. Schematic viev of a clay deposit clnse to the railway linc Broddbo

- Rosshytan, Swedon.

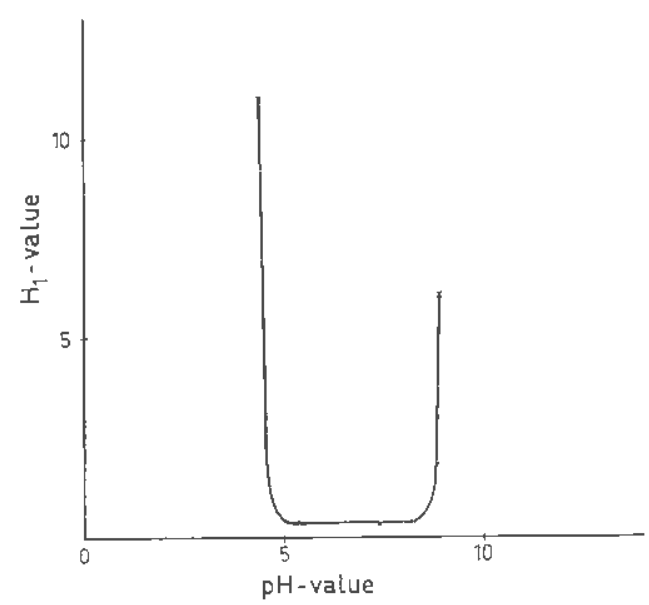

Fig. 3. Influence of alkati on the $\mathrm{H}_{\mathbf{3}^{-}}$ value of a clay from Rosshyttan (depth $3.0-3.1 \mathrm{~m}$ ).

The $\mathrm{pH}$ as a function of depth is shown in Fig. 4 and, in agreement with the above discussion, the clay should be most sensitive at the bottom. 'l'he sensitivity curve (Fig. 4) shows that this is the case. 'l'he agreement between the $\mathrm{pH}$ and the sensitivity agrees with the above thcory.

A photograph of a clay core is shown in Fig. 5 .

A gcological examination of the core has been made by T'. N. A. Jerbo, Geotechnical Department of the Swedish Railways. The glacial part of the core was proved to be sedimented in fresh water, thus not in saline or brackish water. This clay contains a relativcly large amount of organic material. By using a special type of pollen analysis, Mr. Jerbo has succeeded to confirm that
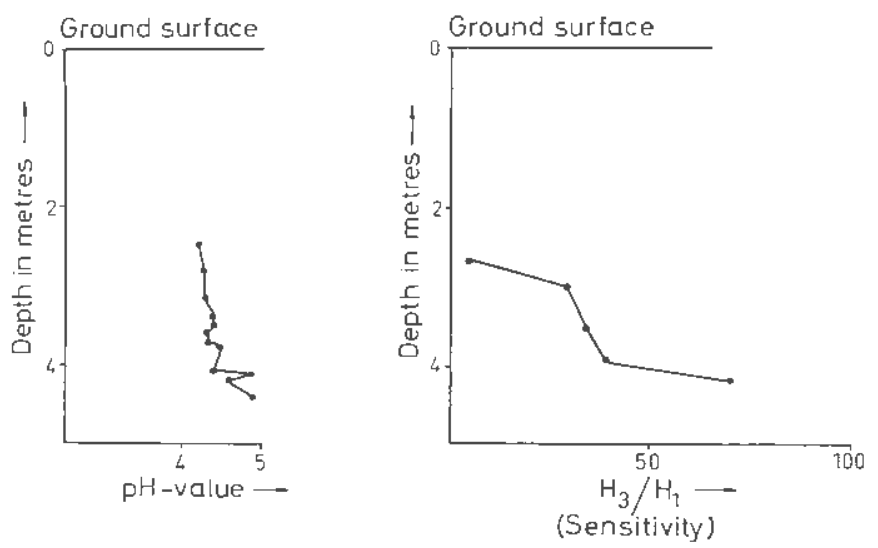

Fig. 4. Comparison between $\mathrm{pH}$-value and sensitivity $\left(\mathrm{H}_{3} / \mathrm{H}_{1}\right)$ for a humic penetrated clay from Rosshyttan. 


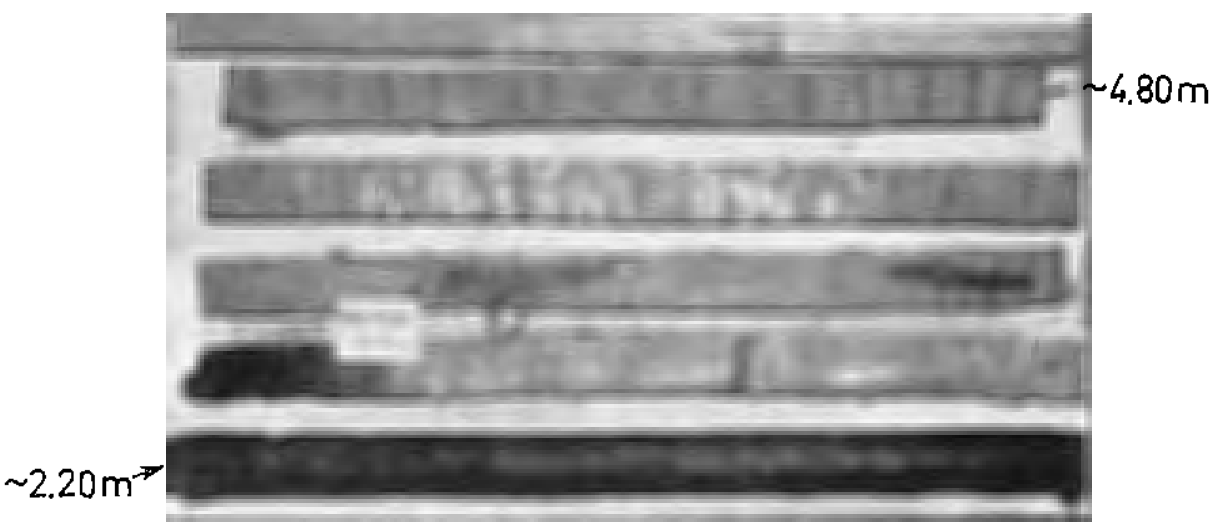

Fig. 5. Photograph o[ a clay core [rom Rosshyttan, Sweden.

the organic material in the clay is not derived from organisms sedimented together with the clay material. The clay has undoubtedly received its humus content by infiltration from the peat deposit.

Jerbo has also investigated the occurrence of peat and quick clay at various sites in Sweden and has already found some fifty places where quick clay peptisized by humic substances appears to exist.

Some of the most important places occur on the coast of the Baltic Sea where deposits of fresh water-sedimented quick clay are often situated in the vicinity of layers of organic material. Suspicions have arisen that the organic layer and the resultant clay destruction in its vicinity contributed to the extensive landslide in Kramfors and an examination will therefore be carried out as soon as possible.

Reports on the geological examination of the core taken from Rosshyttan and of the work in Kramfors will be published later by the Swedish Railways.

Quick clays of this kind seem to exist even in other countries. Newland and Alley (1955) describe a dark grey clay from Whangamarino, New Zealand, geologically proved to have originally been sedimented in fresh water. This clay underlies a 15-foot layer of peat and was found to be a quick clay.

In Switzerland, fresh water-sedimented quick clays have also been said to exist. Dispersing processes of the kind described above are mentioned by Hager (1948). He maintains that hydroxyl ions coming from the destruction of soil and clay minerals together with organic material will cause a dispersion of the soil material.

Grim (1948) points out that certain chemicals will change the orientation of the water adsorbed on the clay. He has also dealt briefly with the question of the adsorption of organic material on clay.

Emerson (1959) has shown that the organic material in sodium clays causes a dispersion of the clay.

On the other hand, the organic dispersing agents described in the present work do not necessarily consist chemically of sodium humate. 
Bloomfield (1956) has made a cletailed study of the dispersion of kaolinite by different leaf extracts. He found that the activity of extracts of Dacrydium franklinii leaves appeared to be caused by their polysaccharide content and that of Agathis sautralis bark by polyphenols. The active components of aspen leaves include a polysaccharide and an acid dispersing agent.

In our case, where the dispersing agents are formed by chemical processes in peat, it seems possible that polysaccharides, oxalates and similar components can also be formed, but a complete chemical study of these processes has not yet been carried out.

In this connection, the dispersing properties of lignin preparations (cf. Lawson 1951) should, in addition, be mentioned.

It is also of interest that tannin preparations (quebracho) are used as dispersing agents for clay in the drilling mud industry (cf. Rogers, 1948, and Alexander, 1946). Tannin can be formed by chemical processes in humus (German Patent, No. 708466,1941 ) and can play some part in the quick clay formation.

\section{Influence of dispersing agents on the strength of a clay}

In Sweden it is often necessary to reckon with dispersing reactions in natural clays. It is of interest to study the influence of these substances on the mechanical properties. A literature study shows that this problem has not yet been probed sufficiently. It has often been supposed that processes forming quick clays reduce the shear strength of undisturbed clays only slightly whereas the remoulded clays are strongly attacked - a rather conflicting supposition.

In order to study this question, some experiments were carried out. The first experiments with carbonate dispersing agents (cf. Söderblom, 1959, p. 731) confirmed chiefly the difficulty of influencing the shear strength of undisturbed clay. More systematic experiments with different kinds of dispersing agents showed that some peptizisers do in fact reduce the shear strength of undisturbed clays.

In Tables 2 and 3, a series of experiments illustrating this is shown. Slices

Table 2. The effect of peptiziser-solutions on a clay sample (2996)

\begin{tabular}{|c|c|c|c|c|}
\hline \multirow{2}{*}{ Treatment during 24 hours } & \multicolumn{3}{|c|}{ Cone rests } & \multirow{2}{*}{ Notes } \\
\hline & $\mathrm{H}_{3}$ & $\mathrm{H}_{1}$ & $\mathrm{H}_{\mathrm{a}} / \mathrm{H}_{\mathrm{t}}$ & \\
\hline None & 36.4 & 3.50 & 10.4 & \multirow{7}{*}{$\begin{array}{l}\text { Crack in the sample. No disaggrega- } \\
\text { tion } \\
\text { Some disaggregation } \\
\text { Some disaggregation } \\
\text { The clay will disaggregate to disper- } \\
\text { sed powder. The surface destroyed } \\
\text { More disaggregated } \\
\text { The surface disaggregated }\end{array}$} \\
\hline $1 \mathrm{~g} \mathrm{Na}_{2} \mathrm{CO}_{3} 0.51 \mathrm{H}_{2} \mathrm{O} \ldots$ & 36.9 & 0.63 & 58.6 & \\
\hline $2 \mathrm{~g} \mathrm{Na}_{3} \mathrm{CO}_{3} \quad 0.5$ I $\mathrm{H}_{2} \mathrm{O} \ldots$ & 20.7 & 0.76 & 27.2 & \\
\hline $3 \mathrm{~g} \mathrm{Na} \mathrm{CO}_{3} 0.5 \mathrm{I} \quad \mathrm{H}_{2} \mathrm{O} \ldots$ & 14.7 & 0.47 & 31.3 & \\
\hline $1 \mathrm{~g} \mathrm{Na} \mathrm{N}_{2} \mathrm{O}_{3} 0.5 \perp \mathrm{H}_{2} \mathrm{O} \ldots$ & 29.0 & $<0.34$ & $>85.3$ & \\
\hline $2 \mathrm{~g} \mathrm{Na}_{4} \mathrm{P}_{2} \mathrm{O}_{7} \quad 0.51 \mathrm{H}_{2} \mathrm{O} \ldots$ & 22.1 & $<0.34$ & $>65.0$ & \\
\hline $3 \mathrm{~g} \mathrm{Na}_{4} \mathrm{P}_{2} \mathrm{O}_{7} 0.51 \mathrm{H}_{2} \mathrm{O} \ldots \ldots$ & 30.4 & $<0.34$ & $>89.4$ & \\
\hline
\end{tabular}


Table 3. The effect of acid-alkaline solutions on a hunic-infiltrated clay

(Sample 4155, K 6766, Rosenkälla, Sweden

\begin{tabular}{|c|c|c|c|c|}
\hline \multirow{2}{*}{ Treatment during 24 hours } & \multicolumn{3}{|c|}{ Cone tests } & \multirow{2}{*}{ Notes } \\
\hline & $\mathrm{H}_{3}$ & $\mathrm{H}_{\mathbf{l}}$ & $\mathrm{H}_{3} / \mathrm{H}_{1}$ & \\
\hline None & 101.0 & 14.3 & 7.1 & \multirow{6}{*}{$\begin{array}{l}\text { Cracks in the sample, otherwise un- } \\
\text { changed } \\
\text { Unchanged } \\
\text { Cracks in the sample, otherwise un- } \\
\text { changed } \\
\text { Affected on the surfacc. Dispersed ma- } \\
\text { terial precipitatcd } \\
\text { Strongly attacked, the sample almost } \\
\text { disaggregatco. }\end{array}$} \\
\hline Distilled vater & 37.8 & 8.55 & 4.4 & \\
\hline $0.1 \mathrm{~g} \mathrm{HCI}$ in $0.51 \mathrm{H}_{2} \mathrm{O} \ldots$ & 28.2 & 6.95 & 4.1 & \\
\hline $0.2 \mathrm{~g} \mathrm{HCl}$ in $0.5 \mathrm{i} \mathrm{H}_{2} \mathrm{O} \ldots$ & 43.2 & 10.0 & 4.3 & \\
\hline $0.1 \mathrm{~g} \mathrm{YaOH}$ in $0.51 \mathrm{H}_{2} \mathrm{O}$.. & 57.1 & 3.23 & 17.7 & \\
\hline $0.2 \mathrm{~g} \mathrm{NaOH}$ in $0.51 \mathrm{H}_{2} \mathrm{O}$. & 48.0 & 1.14 & 42.1 & \\
\hline
\end{tabular}

of unremoulded clay were placed in solutions of $\mathrm{Na}_{1} \mathrm{P}_{2} \mathrm{O}_{7}$ and $\mathrm{Na}_{2} \mathrm{CO}_{3}$ at different concentrations and the ions were permitted to diffuse into the sample for 24 hours. As seen in the tables, the influence on the shear strength may increase with increasing concentration of the agent.

The circumstances were found to be the same when pcat-impregnatcd slices of clay were placed in different concentrations of $\mathrm{NaOH}$.

These results indicate a reduction in the shear strength of a natural clay by means of dispersing agents, but the general problems associated with the dispersing process have not yot been definitely solved.

\section{Suitable materials for studies of dispersing processes}

Since a natural clay is of heterogeneous composition and is easy to separate into fractions of different particle sizes which react diffcrcntly to dispersion and since the fractions vary relatively in quantity and activity from one clay to another, a different test material would be more suitable for our principle investigations.

The ideal material would be a synthetic clay having reprodicible properties and being available in large amounts, but such a material has hitherto been impossible to find.

Becausc the clay fraction of the Swedish clays consists principally of illite, it would seem suitable to choose illite as a model material.

A fractionated and completely classified illite clay would be the best material in our case but, because of the difficulties involved in producing such a clay, we have initially chosen another material which is more easily obtainable.

In the present methodological studies, kaolinite was chosen as a rather pure material although unfortunately its properties differ to a certain extent from those of the Swedish natural clays. For example, kaolinite generally has a smaller water-adsorbing power than a Swedish clay. The dispersing effects seem 
to be the same for haolinite and natural clay and this fact determined our choise of kaolin for study purposes. However, the various samples of the same material appear to differ from each other, thus making it necessary to test the material carefully before use.

\section{Model studies on kaolin}

The dispersing effect depends on the water content of the system. This can be studied by measuring the dispersibility at different water contentș. In such an investigation, the best method is to plot the results obtained in so-called consistence-curves for the system kaolin-water.

Table 4. Consolidation and dispersing of kaolin-silt and natural clay

\begin{tabular}{|c|c|c|c|c|}
\hline \multirow{2}{*}{ Treatment } & \multicolumn{3}{|c|}{ Conc test } & \multirow{2}{*}{ Notes } \\
\hline & $\mathrm{H}_{\mathrm{s}}$ & $\mathrm{H}_{1}$ & $\mathrm{H}_{3} / \mathrm{H}_{1}$ & \\
\hline Kálin consol. $2 \mathrm{~kg}^{\prime} \mathrm{cm}^{2} 4$ hrs. & 33.2 & 29.4 & 1.1 & \multirow{4}{*}{$\begin{array}{l}\text { Inhomoge- } \\
\text { neous }\end{array}$} \\
\hline Silty finc-sand (coarse material) cons. $2 \mathrm{~kg} / \mathrm{cm}^{2}$. & 1295.0 & 2.0 .5 & 143.9 & \\
\hline $50 \%$ kaolin $+50 \%$ coarse material cons. $2 \mathrm{~kg} / \mathrm{cm}^{2}$ & 95,0 & 2.05 & 46.3 & \\
\hline 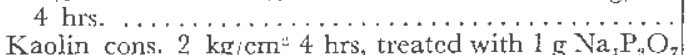 & 33.2 & 16.9 & 2.0 & \\
\hline 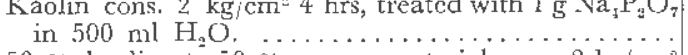 & - & - & - & \multirow{7}{*}{$\begin{array}{l}\text { Liquid } \\
\text { Liquid } \\
\text { I iqquid }\end{array}$} \\
\hline 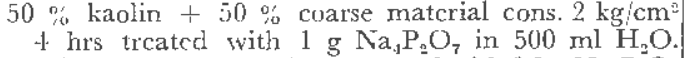 & - & - & - & \\
\hline $\begin{array}{l}\text { Kaolin cons. } 2 \mathrm{~kg} / \mathrm{cm}^{2} 4 \text { hrs, treatcd with } 0.2 \mathrm{~g} \mathrm{Na}_{4} \mathrm{P}_{2} \mathrm{O} \\
\text { in } \overline{3} 00 \mathrm{ml} \mathrm{H}, \mathrm{O} . \ldots \ldots \ldots \ldots \ldots \ldots \ldots \ldots \ldots \ldots\end{array}$ & - & - & - & \\
\hline $\begin{array}{l}50 \% \text { kaolin }+50 \text { coarse materials cons. } 2 \mathrm{~kg}^{2} \mathrm{~cm}^{2} \\
4 \text { hrs, trated with } 0,2 \mathrm{~g} \mathrm{Na} \mathrm{P}_{3} \mathrm{O}_{7} \text { in } 500 \mathrm{ml} \mathrm{H} \mathrm{H}_{2} \mathrm{O} \text {. }\end{array}$ & 431 & 0.36 & 1205 & \\
\hline $\begin{array}{l}50 \text { o kaolin }+50 \text { coarse material cons } 2 \mathrm{~kg} / \mathrm{cm}^{\circ} \\
4 \mathrm{hrs} \text {, treated with } 1 \mathrm{~g} \mathrm{Na} \mathrm{NO}_{3} \text { in } 500 \mathrm{ml} \mathrm{H} \mathrm{H}_{\mathrm{n}} \mathrm{O} \text {. }\end{array}$ & 526 & $<0.34$ & $>1547$ & \\
\hline $\begin{array}{c}50 \text { ofolin }+50 \% \text { coarse matcrial cons. } 2 \mathrm{~kg} / \mathrm{cm}^{\prime \prime} \\
4 \mathrm{hrs} \text {, treated witl } 0.2 \mathrm{~g} \mathrm{Na} \mathrm{Na}_{3} \text { in } 500 \mathrm{ml} \mathrm{H} \mathrm{H}_{3} \mathrm{O} \text {. }\end{array}$ & 386 & 22.1 & 17.5 & \\
\hline 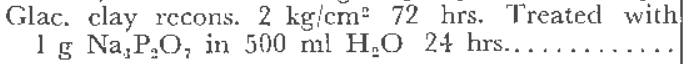 & 163 & 4.71 & 34.6 & \\
\hline
\end{tabular}

\section{EXPERIMENTAL PROCEDURE}

200 grams of kaolin and 100 grams of water were carefully mixed and homogcnized. The remoulded shear strength $\left(\mathrm{H}_{1}\right)$ was determined by a fall cone test. One $\mathrm{ml}$ of water was added from a burette, the mixture carefully homogenized and the resulting $\mathrm{H}_{1}$-value determined. The experiment was continued in this manner until the $\mathrm{H}_{\mathbf{1}}$-value had decreased to a non-measurable quantity $(<0.34) . H_{1}$ was then plotted against the amount of added water.

In Fig. 6, the curve for the system 200 grams kaolin/100 grams water is shown with and without the addition of 1 gram $\mathrm{Na}_{2} \mathrm{CO}_{3}$ to 500 grams of clay as a dispersing agent. The dispersing agent causes the shear strength curve $\left(\mathrm{H}_{1}\right.$-value) to drop much more quickly but the curves scem to approach each other asymptotically at high and low water contents. 


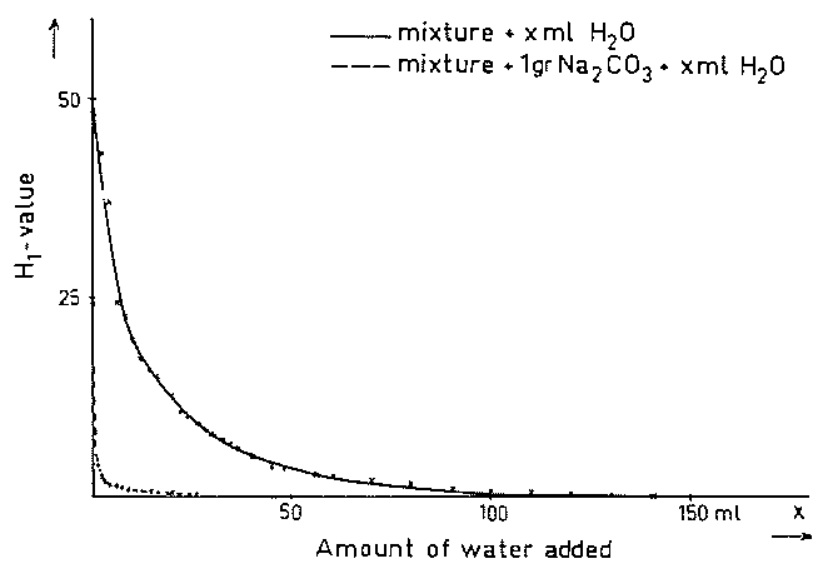

Fig. 6. Influence of water on the $\mathrm{H}_{1}$-value of a mixture of $200 \mathrm{~g}$ dry kaolin and $100 \mathrm{~g}$ water.

The same effect was found when using Swedish natural clay. Fig. 7 shows the corresponding curve for Frescati-clay and carbonate. The curve is very similar to the kaolin curve. Possibly, this phenomenon may explain why quick clay upon consoliclation loses its sensitivity.

If kaolin is clispersed with $\mathrm{Na}_{4} \mathrm{P}_{2} \mathrm{O}_{\eta}$ and the mixture partly dried, an elastic material is obtained which can be formed into a ball. When rapidly stressed, this material gives a brittle rupture and the 100 grams cone test gives a penetration of only a few millimetres. The substance obtained is thus rather firm.

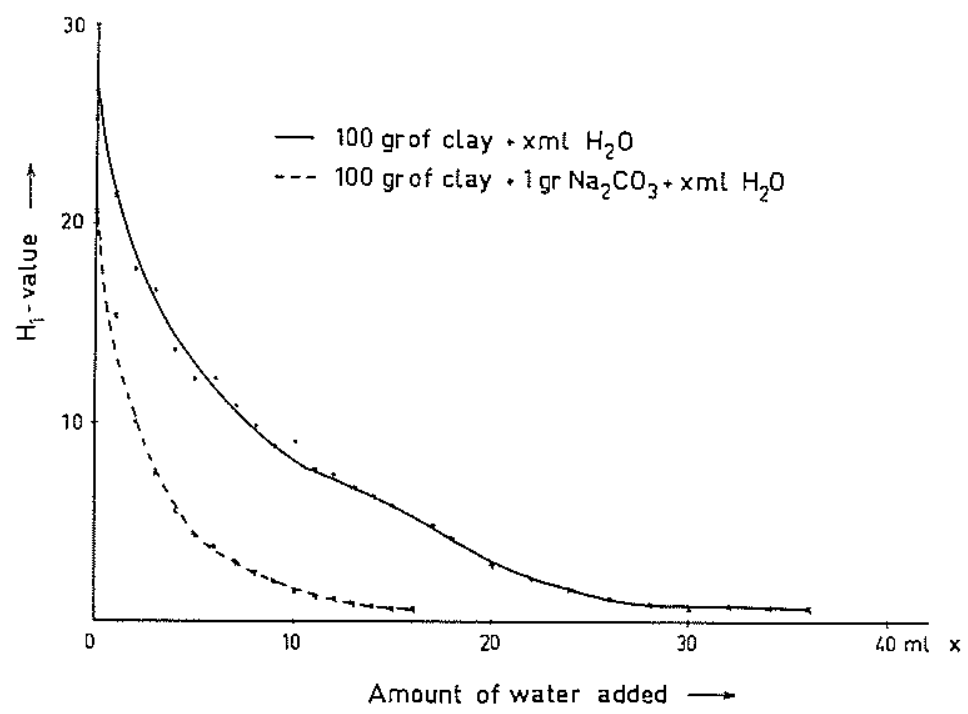

Fig. 7. Influence of water on the $\mathrm{H}_{1}$-value of a remoulded clay from Frescati, Sweden. 
If left under gravitational load for a few seconds, it will disaggregate, giving rise to a shear strength which is too low to be determined by the cone test.

This seems to indicate that the clay has lost its cohesive properties showing dilatancy.

\section{SENSITIVITY EXPERIMENTS}

If an unremoulded dispersible clay sample is treated with a solution of a dispersing agent, no essential difference in the mechanical properties is in most cases noticed until the sample is remoulded and broken down. The fact that the unremoulded shear strength may be differently affected is of special interest for reactions of this kind.

The results obtained in these experiments have lead to the following preliminary point of view.

The quick clays examined are built up of a skeleton of uninfluenced coarse material which is non-cohesive, and this is mixed with cohesive material in which the cohesive properties are reduced by the influence of dispersing agents. The clay is thus sensitive to mechanical changes in the non-colnesive skeleton.

Balls made of kaolin and water were placed in various solutions of a number of dispersing agents of different concentrations. In all cases, the balls were disaggregated to a powder.

The experiments were extended to comprise tests on kaolins which had been consolidated before the chemical treatment. A solution of pyrophosphate was allowed to trickle through the sample after concluded consolidation. Also in this case it was impossible to measure a sensitivity because the sample became a liquid.

This seems to point to the difficulties of building up a high sensitivity by dispersing pure clay material.

In the literature it is concluded that a salt-coagulated material is necessary in order to form a metastable sensitive product. However, the pronounced tendency of the glacial clays to become quick upon treating with dispersing agents and, in particular, the natural fresh water sedimented quick clays contradict such a conclusion.

According to the above, sensitivity should be formed if, instead of purc kaolin, we use kaolin mixed with coarser material. For this reason, consolidation experiments were performed on mixtures of kaolin-silt, and dispersing agents were allowed to trickle through the sample exactly as in the use of pure kaolin. By careful dispersion, very high sensitivities were obtained. If the influence is made stronger, the colloidal material will begin to flow and the system will disaggregate similarly to the case of a natural clay, cf. p. 373 .

In natural quick clay, it seems possible that organic gels will give rise to an increased viscosity. ${ }^{\mathrm{I}}$

The organic material in a clay appears as several different chemical substances - some of which possess dispersing properties. This points to the impossibility of getting a relation between the content of organic dispersing agents in a clay and the carbon content. 
As mentioned above, it is only the colloidal fraction of a natural clay which is influenced by a dispersing agent. Preliminary experiments have shown that cven the colloidal fraction of a clay contains undispersible constituents.

\section{Dispersibility of different types of clays}

Not all types of Swedish natural clays are influenced by dispersing agents and the influence seems to differ for various dispersing agents. Pyrophosphates and oxalates seem to reduce the remoulded shear strength of most Swedish clays but it is very common to find clays that are only slightly affected by carbonates and humates.

Hitherto only qualitative experiments concerning these effects have been made, i.e. we have investigated whether a specially treated clay is dispersible or not. The preliminary tests will be supplemented by quantitative tests.

It is possible by chemical means to transform an undispersible clay into a dispersible form and it scems that the positive ions of the system play a decisive rốle.

The content of exchangeable ions in all the systems investigated was below the critical value specific for the system in question with regard to its incchanical stability. The tests showed essentially that $\mathrm{Na}^{+} \mathrm{Ca}^{2}+$ and $\mathrm{Fe}^{3+}$ clays are dispersible. If an undispersible clay is boiled with $\mathrm{NaCl}, \mathrm{CaCl}_{2}$ or $\mathrm{FeCl}_{7}$ and the clay is then filtered off and leached, it becomes dispersible. The cffect appeared to be greatest in the case of $\mathrm{Fe}^{i+}$.

\section{EXPERIMENTS}

The material used was black sulphide clay from Alvängen having the geotechnical constants shown in Table 5 . The first step in the examination was to expose the sample to salt leaching. According to Table 5, this treatment did not scem to give a quick clay. In both the natural state and in the leached state, the clay was undispersible by humates and carbonates. When the clay, was boiled with dilute $\mathrm{HNO}_{3,}$, the $\mathrm{Fe}^{2+}$ sulphides were dissolved and the iron

Table 5. Influence of salt leaching of the properties of clay from Älvängen, Sweden

\begin{tabular}{|c|c|c|c|c|c|}
\hline \multirow{2}{*}{ Treatment } & \multicolumn{3}{|c|}{ Cone tests } & \multirow{2}{*}{$\begin{array}{c}\text { Rc- } \\
\text { sistance, } \\
\text { electr. } \\
\Omega\end{array}$} & \multirow{2}{*}{ Notes } \\
\hline & $\mathrm{H}_{3}$ & $\mathrm{H}_{\mathbf{i}}$ & $\mathrm{H}_{2} / \mathrm{H}_{1}$ & & \\
\hline None .... & 128 & 24.3 & 5.3 & 34 & Black postglacial sulphide clay. \\
\hline $\begin{array}{l}\text { Dialysis for } 3 \text { weeks........ } \\
\text { Original clay treated with }\end{array}$ & 52 & 12.2 & 4.3 & 620 & Slightly disspersible. \\
\hline $\begin{array}{c}\mathrm{l} \mathrm{g} \mathrm{Na}_{3} \mathrm{CO}_{3} 100 \mathrm{~g} \text { clay } . \\
\text { Dialyzed, treated with I } \mathrm{g} \\
\mathrm{Na}_{3} \mathrm{CO}_{3} 100 \mathrm{~g} \text { clay ...... }\end{array}$ & - & $\begin{array}{r}24.3 \\
3.06\end{array}$ & - & - & $\begin{array}{l}\text { Experiments on remoulded } \\
\text { clay }\end{array}$ \\
\hline
\end{tabular}


was oxidized to $\mathrm{Fe}^{3+}$, this treatment thus corresponding to a boiling of uncispersible clay with $\mathrm{FeCl}_{3}$, and according to the foregoing the clay became dispersible after leaching. The same effect was obtained when the clay was exposed to water dialysis of a long duration, the iron becoming oxidized to $\mathrm{Fc}^{3+}$ and the colour of the clay changing from black to grey. Natural oxidation processes seem however to change this Göta River clay to an easily clispersible material.

\section{Field examinations in the Göta River Valley}

The results of the examination of clay from Älvängen showed that salt leaching alone is not sufficient for making the clay from the Göta River Valley highly sensitive. On the other hand, it is possible to do this by a suitable chemical treatment and subscquent exposurc of the clay to a dispersing process. This indicates the possibility of the existence of natural dispersing processes in the valley and it seems to be of great importance to ascertain whether or not this is the casce. This has revealed quite new aspects concerning the question of clay destroying processes.

The rather rich occurrence of brown mud and peat deposits in this valley and on the ridges points to the possibility of humic dispersing processes similar to those at Rosshyttan.

At certain levels, the clay also has perrmcable layers of silt and sand. In many cases, brown-coloured humic water flows through these layers. This water is relatively acid and possesses a certain hydrostatic pressure.

A clay having such a layer is shown in Fig. 8. Humates penctrate into the clay from this layer. The permeation takes place under acid conditions according to Forslind (for instance, 1948), and may give a stabilization of the water lattice and thus no humates penctrate the individual clay crystals and the clay is not dispersed. At a greater distance from the layer, the clay is alkaline and thus sensitive to the influence of the humates.

The insensitive clay in the vicinity of the layer would on the other hand he casily dispersed by alkali, a fact which is employed in the following.

Clay non infiltrated

Clay infiltrated with humates, alcaline

Clay infiltrated with humates, acid

Coarse layer containing humates

Clay infiltrated with humates, acid

Clay infiltrated with humates, alcaline

Clay non infiltrated

Fig. 8. Penetration of humates in a clay containing a permeable layer. 
Fig. 9. Infuence of alkali on the $\mathrm{H}_{1}$-value of a clay from Göta, Sweden (depth $2.80 \mathrm{~m})$.

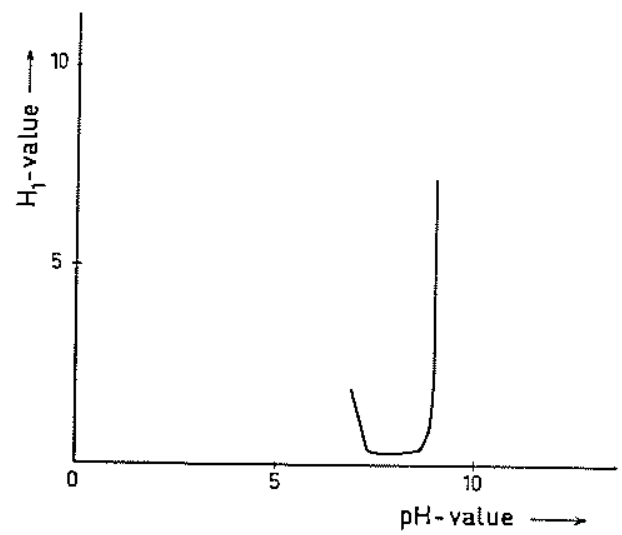

Fig. 9 contains a curve illustrating the influence of alkali on a clay from Göta taken at a level where we have to expect humic infiltration at a sensitivity minimum. The $\mathrm{H}_{1}$-value is lowered by alkali and the curve for the $\mathrm{H}_{1}$ at different $\mathrm{pH}$ is similar to that obtained for the Rosshyttan clay. This indicates clearly the occurrence of processes of the same kind in both cases. Other similar experiments have shown that dispersing processes of this kind are probably relatively common in the Göta River Valley.

Examination of the dispersibility of natural clays have hitherto not been carried out systematically, due to the short time which has elapsed since the detection of these processes in Nature. We have therefore first of all attempted to find a suitable field method.

The method adopted is as follows:

The sensitivity and shear strength is measured by vane borings. Salt sounding curves are taken parallelly. If the clay is salt, this seems to be sufficient for the clay to be assumed insensitive. Hitherto we have not found salt quick clays in Sweden. According to Newland and Alley (1955), such clays exist at least in New Zealand.

If the clay is not saline and not quick, it is tested for dispersibility. For simplicity, remoulded samples are taken with a side-intake sampler from every $1 / 2$ metre. The $\mathrm{H}_{1}$-value is determined by a cone test and, thereafter, the sample is made alkaline with sodium hydroxide until the $\mathrm{H}_{1}$-value has reached a minimum. The quotient of the $\mathrm{H}_{1}$-value in the natural state and the value in the alkaline state is a measure of the dispersibility and the humic permeation of the clay. It is also a rough measure of the sensitivity which, in this special case, can arise as a consequence of increased alkalinity.

If the clay is not dispersible by sodium hydroxide and is not quick but there is nevertheless a peat deposit, an examination is carried out to discover whether humate isolated from the deposit will clisperse the clay or not. If the ciay is dispersed by humate, it is possible that the dispersing agent has not reached the clay. If not, it is considered to be an undispersible type and the possible chemical reactions which may give rise to dispersibility are then studied. 
Table 6. Influence of alkali of clay samples from a profile from Intagan, Sweden

\begin{tabular}{|c|c|c|c|c|c|}
\hline $\begin{array}{c}\text { Depth below } \\
\text { ground surface } \\
\text { in metres }\end{array}$ & $\begin{array}{c}\mathrm{H}_{1} \text {-valuc } \\
\text { before } \\
\text { treatment }\end{array}$ & $\begin{array}{c}\mathrm{H}_{1} \text {-valuc } \\
\text { after } \\
\text { treatment }\end{array}$ & $\begin{array}{c}\text { Dispersibi- } \\
\text { lity }\end{array}$ & pH-value & Notes \\
\hline 3 & 28.4 & 25.0 & 1.1 & 6.8 & \\
3.5 & 16.9 & 12.2 & 1.4 & 7.2 & \\
4.5 & 7.1 & 6.9 & 1.0 & 7.5 & \\
5 & 5.5 & 3.8 & 1.4 & 7.8 & Disp. with peat \\
6 & 1.5 & 1.3 & 1.2 & 7.9 & extr. 4.5 \\
9 & 5.8 & 4.4 & 1.3 & 7.9 & \\
\hline 13 & 8.1 & 5.8 & 1.4 & 7.9 & \\
\hline
\end{tabular}

By examinations of this kind, we have found satisfactory support for our theories in a profile taken from a site near Intagan, Göta River Valley. The strength reduction for sodium hydroxide is very low near the river. Here isolated humates are dispersible (Table 6). The clay is rather alkaline in the whole profile and, at some levels, it is highly sensitive. This shows that the insensitive parts of the profile in this case probably lack sufficient amounts of dispersing agents.

At a greater distance from the river (about $500 \mathrm{~m}$ ), the clay is more dispersible by alliali (Fig. 10). This indicates a greater permeation than that near the river. The clay is most sensitive at the bottom where it is also most alkaline.

At a still greater distance from the river, the clay is very insensitive but: shows a great dispersibility when treated with sodium hydroxide (Fig. 11). This indicates a high permeation. At depths of 3.5 and $5.5 \mathrm{~m}$, there are distinct layers of sand which are brown-coloured due to the flowing water. At these levels (especially at $5.5 \mathrm{~m}$ ), the $\mathrm{pH}$ value shows a minimum and the $\mathrm{H}_{1}$-value reaches a maximum. According to the theory given here, the $\mathrm{H}_{1}$ value should be low at levels where the $\mathrm{pH}$ is high and the figure also shows that this is in fact the case. In the vicinity of the coarser layers, the clay should show the highest dispersibility and this too appears to be correct. If this clay is alkalized, it will show the highest sensitivity at the levels where it is most dispersible and, if the permeation is the same at a place where the clay is
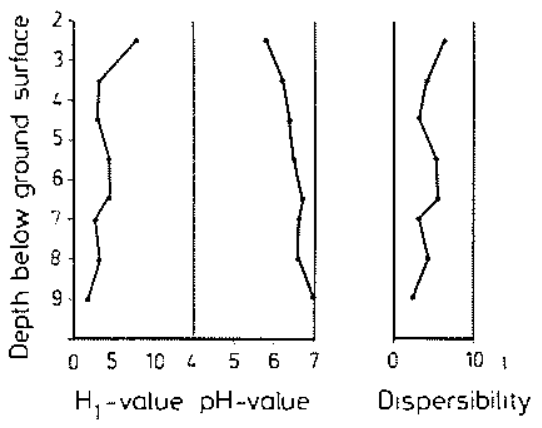

lïig. 10. Infuence of alkali on a clay profile from Intagan, Sweden. Depths in metrcs. 


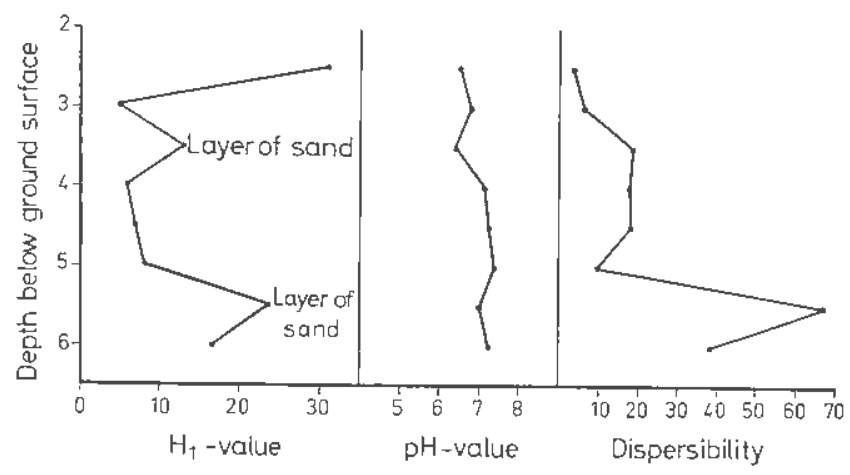

Fig. 11. Influence of alkali on a clay profile from Intagan, Sweden. Depths in motres.

more alkalized, the sensitivity curve should correspond to the dispersibility curve. Some sensitivity curves from this section indicate such a relation (Fig;. 12).

The results obtained show that, in this section, we have to reckon with a permeation of humic material coming from the vicinity of the ridge and following the coarser layer in the clay. An examination showed that, on the top of the ridge, there are marshy grounds containing peat with dispersing propertics. Maps indicate that peat deposits of this lind are common in the Göta River Valley and consequently we must often reckon with processes of this lind. The lateral destruction of the clay will also explain why quick clays often occur in a certain region situated between the river and the ridge.

Natural carbonates and other agents may play an important part but, owing to the obvious character of the humate processes, the possible carbonate processes have not yet been examined.

It is of interest to investigate whether a correlation exists between large landslides and peat deposits. Preliminary examinations have been made in Göta and Surtc. In Göta, there is a large deposit containing a strong dispersing agent and this deposit has two outflows where permcation nay have occurred and which are situated behind a recent large slide. In Surte, too, some peat deposits can be found behind the landslide there.

Fig. 12. Shear strength, to the right, and scnsitivity curves of a clav profile from Intagan, Sweden. Depths in metres.

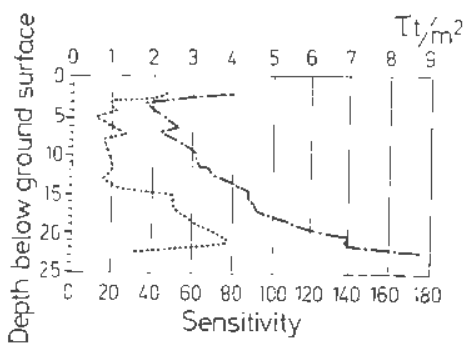




\section{References}

Alexhinder, J., 1946: Colloid Chemistry. Fol 6 p. $518-522$.

Bloomfreld, C., 1956: The dellocculation of kaolinite by leaf extracts. - Trans. Intern. Congr. Soil. Sci. 6. Congr. Paris. Vol B p. 27-32.

Enerson, W. W., 1959: The Structure of Soil Crumbs. … J. Soil Sci. Vol 10 Nr 2 p. 242.

Forsutwd, E., 1948: The clay-water system. - Swed. Cement and Concrcte Rcs. Inst. R. Inst. Technol., Slockholm, Nr 11 .

Grim, R. E., 1948: Some Fundamcntal Factors Influencing the Properties of Soil Materials. Proc. 2. Intern. Conl. Soil Mech. Found. Engng. Vol 3 p. 8-12.

Hager, G., 1948: Dic Kolloidbestandsteile des Bodens und die Methoden ihrer Erkennung in Handbuch der Bodenlehre, Bd 7 p. 74.

Lawson, L. L. and KeILEN, J. J., 1951 : Pinewood Lignin as a ceranic deflocculant. - Amer. Cer. Soc. Bull. 30 p. $143-147$.

NEWLAND, P. L. and ALLEy, P. H., 1955 : Results of some Investigations on two Sensitive Clays. - New Zeal. Engng. Vol 10 p. $403-406$.

Rogers, W., 1948: Composition and Properties of Oil Wdl Drilling Fluids, p. $284 \mathrm{fr}$.

Söjerifom, R., 1959: Aspects on sone Problems of Geotechnical Chemistry. — GFF Bd 81 H 4 p. $727-32$. 